\title{
New German Library Service During the War
}

A

FTER enemy troops had surrendered, allied intelligence teams proceeded to investigate important industrial and scientific "targets" in occupied areas. These. teams, composed of scientific specialists and technicians, were assigned the mission of reporting on latest research developments. In some instances it was discovered that processes and methods adopted by the enemy, especially Germany, represented improvements over those known in the United States, Great Britain, or other allied nations. The present article is concerned with a noteworthy development in German library services, as revealed in documents gathered by the "Alsos" Mission, Military Intelligence Service of the War Department (R.F.R. File 228), now deposited in the Library of Congress. ${ }^{1}$

Nazi Germany's central research agency was the Reichsforschungsrat (R.F.R.), established by Göring in 1942 as successor to the Forschungsgemeinschaft (I937-4I) and the Notgemeinschaft der Deutschen Wissenschaft (prior to I937). In direct charge of the R.F.R. was a prominent S.S. man, Prof. Mentzel, who reported to Göring through Dr. Görnnert.

Early in I943 Mentzel asked Albert Predeek, librarian of the Berlin Institute of Technology (Technische Hochschule), to draw up a plan for the establishment of a central research card index. In compliance, Predeek submitted a detailed outline on

1 Available on microfilm through the Office of the Publication Board, U.S. Department of Commerce, Washington 25, D.C. Order No. PB r 2751 .
Feb. I8, I943, envisaging a staff of twentyone scientific analysts, fourteen librarians, and nineteen clerical assistants, and proposed an annual budget of 476,000 Reichsmarks (about \$I90,000 at prewar exchange rates), of which 68 per cent was allotted to salaries, 7 per cent to supplies, equipment, and photoduplication, and 25 per cent to printing.

Predeek pointed out that Germany possessed no central agency capable of giving up-to-date information on current scientific and technical research activities: Who was engaged in what projects? Where? Under what sponsorship? What were the results? To answer such questions it would be necessary ( $I$ ) to maintain a card index of all scientists, (2) to publish abstracts of results of research, (3) to collect and make available all scientific and technical publications, and (4) to provide reference service and photoduplication.

More specifically:

I. The card index was to cover approximately 6500 scientists, giving for each his address, biographical data, research projects, and publications. The subject index was expected to carry at least 100,000 headings.

2. The abstracting journal would present about 3000 abstracts a month, with annual subject and author indexes. Fields already adequately abstracted in other media would be excluded.

3. Acquisition of literature was to include journals, research reports, dissertations, trade publications, and bibliographies. The number of subscriptions was expected to be 3300 .

4. Reference service was to be provided for a fee. Translation services would also be 
available. Photostats and microfilms would be offered at cost.

Predeek suggested that the new service should be located in the library building of the Technische Hochschule, Berlin, and that the work should be conducted in close cooperation with the library staff in order to utilize the experiences gained by that staff in a similar enterprise in the field of technology.

\section{Albert Predeek}

On Mar. 24, I943, sixty-year-old Predeek was appointed chief of the agency for which he had drawn the blueprints. Officially designated as Kartei und Informationsstelle, it was to provide research reference service in the fields of technology, science, medicine, agriculture, and forestry. Predeek's position as chief was merely a part-time assignment without remuneration (except for a small expense account of IOO Reichsmark a month). His appointment was strongly endorsed by Mentzel. Predeek, said Mentzel in a letter to Görnnert, was a veteran of World War I, a reserve captain, a recipient of the Iron Cross, and an eminent librarian. He had visited the United States in 1937 for the purpose of studying libraries and bibliographic methods. Mentzel had known him for many years and was prepared to vouch for the integrity of his character and his enthusiasm for library service. Nothing was mentioned about Predeek's attitude toward the Nazi Party. Had he been an enthusiastic party member, it would most certainly have been emphasized in the letter recommending his appointment; yet it cannot be denied that Predeek was quite eager to contribute his skills and services to the Nazi war effort.

The first step in establishing the card index of research projects consisted of mailing questionnaires to the personnel of all private and tax-supported research institu- tions. Objections to disclosure of military or trade secrets were overruled, although it was agreed to use such data only for official purposes. Returns, supplemented by bibliographic information, were arranged in an official catalog to which the public was not allowed access. The catalog to which the public did have access consisted of three parts: (I) a catalog of scientific personnel, (2) a catalog of research institutes, and (3) a detailed subject index to the other two catalogs and to scientific and technical research reports.

Just about the time that the information service was beginning to function a serious interruption occurred: The library of the Technische Hochschule was destroyed by allied air attacks on Nov. 22, 1943. In December the offices were moved to Rossla, a village in the Harz Mountain area. By the end of June 1944, the agency had been restored to fair working condition. New excitement was caused on July 16 when Predeek received a telegram ordering him to move his entire establishment out of Rossla within two weeks. Military necessity of an unspecified nature was given as the reason. Predeek's protest resulted in a postponement of the evacuation date and finally a revocation of the initial order. On Aug. 19, 1944, Predeek informed Mentzel that the Kartei was ready for use once again.

\section{Operation}

In December 1944 Predeek issued a circular announcing to German science and industry the services which the Kartei was now ready to provide. Information about research projects of 25,000 scientists and the work of 3,000 research institutes and laboratories was available through a detailed subject index arranged under 45,000 headings.

(Continued on page 236) 
of cataloging of microfilm and related materials, two things should be kept in mind: First, it must be decided what type of service catalogs are to render and what type of patron is to be served principally. Probably, we shall incline more and more to the subject approach-at least, in current largescale cooperative cataloging projects more attention is being paid to this kind of detail than was before felt necessary. For the full coverage of a book from the subject point of view, we may have to wait, however, for some device such as Vannevar Bush's filmed catalog cards, with code indicators in dot form, to be scanned at tremendous speeds by photoelectric eyes and rephotographed on the fly by high-speed cameras to form films of selected cards for the formation of bibliographies.

\section{New German Library_Service}

\section{(Continued from page 225)}

The principal questions Predeek's card catalog was prepared to answer were: (I) Who was doing research in what field? (2) What had been the results of previous research? Information would be furnished free of charge. The fields covered were general science, engineering, medicine, agriculture, and forestry. In fields adequately covered elsewhere, notably chemistry and mining, the card index was to supply only supplementary data. Extension of coverage to the social sciences and humanities was contemplated.

How effective the Kartei was in aiding the Nazi war effort could not be ascertained from the sources at hand. Had such a research information service been available earlier in the war, it would undoubtedly have helped to expedite emergency research
The second thing that should be remembered is this: The only device yet evolved to avoid duplication of work and multiplication of the costs of cataloging is centralized and cooperative cataloging. Once standardization of approach is achieved, this shall follow. In the meantime, so long as there remains this chaos of varying sizes of film, types of projector equipment, methods of housing and storing materials, there will exist the problem of hand-typed, custommade cards, tied to the present card cataloging system. It is only when microphotography can break away from the present routines that the fullest measure of independent and efficient service can be rendered, as independent as the government document collections but much more versatile, supplementing and, in part, even supplanting them.

in Germany. It was an attempt to avoid duplication of effort and to coordinate scientific research activities on a national scale, but it came too late in the game to be of much value.

Several facts seem significant concerning this German venture in research library service: ( 1 ) at a time of critical shortage of personnel and materials, library techniques received recognition as indispensable tools in an important governmental enterprise; (2) professionally trained library personnel was recruited for key positions within the framework of science and technology; (3) bibliographic investigation was deemed so essential a phase of scientific research that a special administrative unit was established and substantial funds appropriated for accomplishing the work. 